\title{
Summary of Canadian Guidelines for the Initial Management of Community-acquired Pneumonia: An evidence-based update by the Canadian Infectious Disease Society and the Canadian Thoracic Society
}

\author{
Lionel A Mandell MD FRCPC ${ }^{1}$, Thomas I Marrie MD FRCPC ${ }^{2}$, \\ Ronald F Grossman MD FRCPC FACP ${ }^{3}$, Anthony W Chow MD FRCPC FACP ${ }^{4}$, \\ Robert H Hyland MD FRCPC ${ }^{5}$, and the Canadian CAP Working Group*
}

\begin{abstract}
LA Mandell, TJ Marrie, RF Grossman, et al. Summary of Canadian Guidelines for the Initial Management of Community-acquired Pneumonia: An evidence-based update by the Canadian Infectious Disease Society and the Canadian Thoracic Society. Can Respir J 2000;7(5):237-248.

Community-acquired pneumonia (CAP) is a serious illness with a significant impact on individual patients and society as a whole. Over the past several years, there have been significant advances in the knowledge and understanding of the etiology of the disease, and an appreciation of problems such as mixed infections and increasing antimicrobial resistance. The development of additional fluoroquinolone agents with enhanced activity against Streptococcus pneumoniae has been important as well.

It was decided that the time had come to update and modify the previous CAP guidelines, which were published in 1993. The current guidelines represent a joint effort by the Canadian Infectious Diseases Society and the Canadian Thoracic Society, and they address the etiology, diagnosis and initial management of CAP. The diagnostic section is based on the site of care, and the treatment section is organized according to whether one is dealing with outpatients, inpatients or nursing home patients.
\end{abstract}

Key Words: Canada; Community-acquired pneumonia; Guidelines

Pour le résumé, voir page suivante

\footnotetext{
Financial support for the guidelines was provided by Abbott Laboratories Limited, Pfizer Canada Inc, Ortho-McNeil, Bayer Inc, Bristol-Myers Squibb Canada Inc and Aventis-Pharma

*Members include Dr TJ Marrie (University of Alberta, Edmonton, Alberta); Dr SD Shafran (University of Alberta, Edmonton, Alberta); Dr AW Chow (University of British Columbia, Vancouver, British Columbia); Dr SK Field (University of Calgary, Calgary, Alberta); Dr J La Forge (Université Laval, Quebec City, Québec); Dr G Zhanel (University of Manitoba, Winnipeg, Manitoba);

Dr LA Mandell (MCMaster University, Hamilton, Ontario); Dr C Rotstein (MCMaster University, Hamilton, Ontario); Dr CKN Chan (University of Toronto, University Health Network, Toronto General Site, Toronto, Ontario); Dr RF Grossman (QEII Health Sciences Centre, Halifax, Nova Scotia); Dr RH Hyland (St Michael's Hospital, Toronto, Ontario); Dr DE Low (Mount Sinai Hospital, University of Toronto, Toronto, Ontario); Dr A McIvor (University of Toronto, Toronto, Ontario); Dr JG Bartlett (Johns Hopkins University, Baltimore, Maryland); Dr GD Campbell Jr (Louisiana State University, Baton Rouge, Louisiana); and Dr MS Niederman (SUNY, Mineola, New York) Correspondence and reprints: Dr Lionel Mandell, Department of Medicine, McMaster Medical Unit, Henderson Campus, 711 Concession Street, Hamilton, Ontario L8V $1 \mathrm{C3}$

Received for publication July 24, 2000. Accepted July 31, 2000
} 
Résumé des lignes de conduite canadiennes relatives au traitement initial de la pneumonie d'origine communautaire : mise à jour fondée sur des preuves, préparée par la Société canadienne des maladies infectieuses et la Société canadienne de thoracologie

RÉSUMÉ : La pneumonie d'origine communautaire (POC) est une maladie grave qui a d'importantes répercussions sur le patient lui-même et sur la société dans l'ensemble. Au cours des dernières années, on a fait d'énormes progrès dans les connaissances et la compréhension que nous avons de l'étiologie de la maladie et dans l'appréciation des problèmes comme les infections mixtes et l'augmentation de la résistance antimicrobienne. La mise au point de nouveaux produits à base de fluoroquinolone présentant une activité accrue contre Streptococcus pneumoniae a aussi joué un rôle important.

Le temps est venu de mettre à jour et de modifier les lignes de conduite relatives à la POC, qui ont été publiées en 1993. Les présentes lignes de conduite sont le fruit du travail conjoint de la Société canadienne des maladies infectieuses et de la Société canadienne de thoracologie; elles portent sur l'étiologie, le diagnostic et le traitement initial de la POC. La partie traitant du diagnostic est structurée en fonction des milieux de soins, et celle portant sur le traitement se divise en trois catégories : les patients externes, les patients hospitalisés et les patients placés en maison de soins infirmiers.

$\mathrm{C}$

ommunity-acquired pneumonia (CAP) remains a serious illness with a significant impact not only on individual patients but on society as a whole. Guidelines for the initial antibiotic management of CAP were developed in Canada in 1993 (1), and subsequently by the American Thoracic Society (ATS) that same year (2) and the Infectious Diseases Society of America (IDSA) in 1998 (3). Each set of guidelines has its own strengths and weaknesses, but individually and collectively they have helped to organize and codify our approach to the patient with CAP. Perhaps most importantly, they have highlighted the weaknesses and deficiencies in this area, and have raised important questions for present and future research.

As a result of the developments that have taken place in the past several years, it became clear that the Canadian guidelines needed to be updated and revised. The present document is a joint effort of the Canadian Infectious Diseases Society (CIDS) and the Canadian Thoracic Society (CTS), and is hopefully the first of many such collaborations. This paper is the shortened version of the manuscript, with the key tables and figures included. Readers interested in the more extensive document are referred to the August 2000 issue of Clinical Infectious Diseases (4). These guidelines are evidence based. A hierarchical evaluation of the strength of evidence, modified from the Canadian Task Force on the Periodic Health Examina- tion (5), was used. Well-conducted randomized, controlled trials constitute strong or level I evidence; well-designed, controlled trials without randomization (including cohort and case-control studies) constitute level II or fair evidence; and expert opinion, case studies, and before and after studies are level III (weak) evidence.

CAP, together with influenza, is the sixth leading cause of death in the United States, with an estimated four million cases occurring annually. It accounts for 600,000 hospital admissions and 64 million days of restricted activity/year in the United States $(6,7)$. The risk factors for pneumonia in individuals 60 years of age and older are the following: alcoholism - relative risk (RR) 9.0; asthma - RR 4.2; immunosuppression - RR 1.9; institutionalization - RR 1.8; and 70 years of age and older compared with 60 to 69 years of age - RR 1.5 (8). For pneumococcal infections, the following risk factors have been described: dementia, seizure disorders, congestive heart failure, cerebrovascular disease and chronic obstructive pulmonary disease (COPD) (9).

\section{ETIOLOGY}

There are over 100 microbial causes of pneumonia, and almost all have been isolated from pulmonary tissue at least once. The difficulty is that one cannot obtain pulmonary tis-

TABLE 1

Etiology of community-acquired pneumonia treated on an ambulatory basis

\begin{tabular}{|c|c|c|c|c|c|c|c|c|}
\hline \multirow[b]{2}{*}{ Reference } & \multirow[b]{2}{*}{ Location } & \multirow[b]{2}{*}{ Date } & \multirow[b]{2}{*}{$\mathbf{N}$} & \multicolumn{5}{|c|}{ Etiology (\%) } \\
\hline & & & & S pneum & H influen & M pneum & C pneum & Unknown \\
\hline 12 & $\begin{array}{l}\text { Goteborg, } \\
\text { Sweden }\end{array}$ & 3 years* & 54 & $5(9)$ & $6(12)$ & $20(37)$ & ND & $41 \%$ \\
\hline 13 & $\begin{array}{c}\text { Halifax, } \\
\text { Nova Scotia }\end{array}$ & $\begin{array}{c}\text { November } 1991 \\
\text { to March } 1994\end{array}$ & 149 & 1 & 1 & $34(22.8)$ & $16(10.7)$ & $48 \%$ \\
\hline $14^{+}$ & $\begin{array}{l}\text { Neuchatel, } \\
\text { Switzerland }\end{array}$ & 4 years* & 161 & $17(11)$ & $3(2)$ & $28(17.4)$ & ND & $47 \%$ \\
\hline $15^{+}$ & $\begin{array}{l}\text { Amherst, } \\
\text { Nova Scotia }\end{array}$ & $\begin{array}{l}\text { July } 1989 \\
\text { to June } 1990\end{array}$ & 75 & - & - & $22(29)$ & $1(5.3)$ & $55 \%$ \\
\hline Total & & & 439 & $23(5)$ & $10(2.3)$ & $104(24)$ & & $211(48 \%)$ \\
\hline $95 \% \mathrm{Cl}$ & & & & -3.7 to 14 & -5 to 12 & 11 to 38 & & 38.6 to 56 \\
\hline
\end{tabular}

*Start and stop dates not available; ${ }^{\dagger} 8.7 \%$ required hospitalization in Erard et al's study (14), 35\% in Langille et al's study (15). C pneum Chlamydia pneumoniae; $\mathrm{H}$ influen Haemophilus influenzae; M pneum Mycoplasma pneumoniae; ND No data; $\mathrm{S}$ pneum Streptococcus pneumoniae 
TABLE 2

Selected studies showing the etiology of community-acquired pneumonia requiring hospitalization

\begin{tabular}{|c|c|c|c|c|c|c|c|c|c|c|}
\hline \multirow[b]{2}{*}{ Reference } & \multirow[b]{2}{*}{ Location } & \multirow[b]{2}{*}{ Date } & \multirow[b]{2}{*}{$\mathbf{N}$} & \multicolumn{7}{|c|}{ Etiology (\% of total) } \\
\hline & & & & $\begin{array}{c}S \\
\text { pneum }\end{array}$ & $\begin{array}{c}H \\
\text { influen }\end{array}$ & $\begin{array}{c}S \\
\text { aureus }\end{array}$ & $\begin{array}{c}L \\
\text { pneum }\end{array}$ & $\begin{array}{c}M \\
\text { pneum }\end{array}$ & $\begin{array}{c}C \\
\text { pneum }\end{array}$ & AGNR \\
\hline 10 & $\begin{array}{c}\text { Halifax, } \\
\text { Nova Scotia }\end{array}$ & $\begin{array}{c}\text { November } 1981 \\
\text { to March } 1987\end{array}$ & 588 & $52(8.8)$ & $26(4.4)$ & $22(3.7)$ & $14(2.3)$ & $39(6.6)$ & - & $19(3.2)$ \\
\hline 16 & Pittsburgh, USA & $\begin{array}{l}\text { July } 1986 \\
\text { to June } 1987\end{array}$ & 359 & $55(15.3)$ & 39 (10.9) & $12(3.3)$ & $22(6)$ & $7(2)$ & $22(6.1)$ & $21(5.9)$ \\
\hline 17 & $\begin{array}{l}\text { Columbes, } \\
\text { France }\end{array}$ & $\begin{array}{l}\text { February } 1983 \\
\text { to January } 1984\end{array}$ & 116 & $30(26)$ & $13(12)$ & $3(2.5)$ & $5(4)$ & $4(3.5)$ & - & $8(7)$ \\
\hline $18^{*}$ & $\begin{array}{l}\text { Oulu, } \\
\text { Finland }\end{array}$ & $\begin{array}{c}\text { May } 1986 \\
\text { to May } 1987\end{array}$ & 125 & $69(55)$ & $14(11)$ & - & - & $6(5)$ & $54(43)$ & $1(1)$ \\
\hline $19 *$ & Umea, Sweden & $\begin{array}{l}\text { December } 1982 \\
\text { to November } 1984\end{array}$ & 196 & $63(32)$ & $8(4)$ & $3(1.5)$ & $3(1.5)$ & $13(6.6)$ & - & $1(0.5)$ \\
\hline 20 & Baltimore, USA & $\begin{array}{l}\text { November } 1991 \\
\text { to November } 1991\end{array}$ & 385 & 69 (17.9) & $28(7.3)$ & $14(3.6)$ & $13(3.4)$ & $3(0.8)$ & $14(3.6)$ & $26(6.8)$ \\
\hline $21^{*}$ & Southern Israel & $\begin{array}{c}\text { November } 1991 \\
\text { to November } 1992\end{array}$ & 346 & $148(42.8)$ & $19(5.5)$ & - & - & $101(29.2)$ & $\begin{array}{r}62 \\
(17.9)\end{array}$ & - \\
\hline 11 & Ohio, USA & 1991 & 2776 & $351(12.6)$ & $184(6.6)$ & $94(3.4)$ & - & $\begin{array}{l}404 / 1244 \\
(32.5)\end{array}$ & $\begin{array}{c}172 / 1923 \\
(8.9)\end{array}$ & $124(4.5)$ \\
\hline \multirow[t]{2}{*}{$\begin{array}{l}22 \\
23\end{array}$} & $\begin{array}{l}\text { Leiden, } \\
\text { Netherlands }\end{array}$ & 1985 & 334 & $90(27)$ & $26(8)$ & $4(1)$ & $8(2)$ & $19(6)$ & - & $11(3.2)$ \\
\hline & Arkansas, USA & 1985 & 154 & $8(5)$ & $2(1)$ & $7(5)$ & $6(4)$ & $3(2)$ & $8(5)$ & $7(5)$ \\
\hline Total & & & 5379 & $935(17.3)$ & $359(6.6)$ & 159 (2.9) & $70(1.3)$ & $\begin{array}{c}598 / 4361 \\
(13.7)\end{array}$ & $\begin{array}{l}332 / 3292 \\
(10.1)\end{array}$ & $218(4.05)$ \\
\hline $95 \% \mathrm{Cl}$ & & & & $\begin{array}{c}12.9 \text { to } \\
35.4\end{array}$ & $\begin{array}{c}4.5 \text { to } \\
9.5\end{array}$ & $\begin{array}{c}1.1 \text { to } \\
3.6\end{array}$ & $\begin{array}{c}0.8 \text { to } \\
3.7\end{array}$ & $\begin{array}{c}1.2 \text { to } \\
17.6\end{array}$ & $\begin{array}{c}-1.2 \text { to } \\
17.6\end{array}$ & $\begin{array}{c}1.8 \text { to } \\
5.5\end{array}$ \\
\hline
\end{tabular}

* Serological tests for Streptococcus pneumoniae (usually antibodies to pneumolysin or pneumolysin complexes) used to diagnose pneumococcal pneumonia in addition to blood and, in some cases, sputum culture. AGNR Aerobic Gram-negative rods (such as Escherichia coli, etc); C pneum Chlamydia pneumoniae; $\mathrm{H}$ influen Haemophilus influenzae; L pneum Legionella pneumophila; M pneum Mycoplasma pneumoniae; $\mathrm{S}$ aureus Staphylococcus aureus

sue routinely and, hence, the practising clinician must rely on the results of blood, sputum or pleural fluid culture, and the results of serological tests to make an etiological diagnosis. Blood cultures are positive in only $6 \%$ to $10 \%$ of patients with pneumonia, and pleural fluid is usually obtained only from patients with a complicated pleural effusion. Sputum is obtained for culture in about one-third of the patients who present with pneumonia, but because sputum passes through a heavily colonized oral cavity, any pathogen isolated from this specimen can at best only be presumed to be the cause of the pneumonia (10). Because of this, investigators have categorized the etiology of pneumonia as definite, probable or possible (11).

Definite infection is defined as the isolation of a pathogen from blood or pleural fluid with a fourfold or greater rise in antibody titre to Legionella pneumophila, Mycoplasma pneumoniae, Chlamydia pneumoniae, respiratory syncytial virus or influenza antigens. Isolation of Legionella species from respiratory secretions is always considered definite evidence that this pathogen is responsible for the pneumonia. A positive Legionella species urinary antigen test is also considered definite evidence that this pathogen is causing an infection.

Probable infection is defined as the isolation of Staphylococcus aureus, Streptococcus pneumoniae, Haemophilus influenzae, Moraxella catarrhalis, Enterobacteriaceae or Pseudomonas aeruginosa from purulent sputum (sputum with moderate or large numbers of neutrophils seen on Gram stain) in which a compatible organism was seen in moderate or large amounts on sputum Gram stain.

Possible infection is defined as the isolation of pneumonia pathogens other than Legionella species from a culture of purulent sputum seen on a Gram stain: predominance of Gram-positive diplococci (possible diagnosis of infection with $S$ pneumoniae assigned) or Gram-positive cocci in clusters (possible diagnosis of infection with $S$ aureus assigned), indicative of possible infection due to either of these agents; an antibody titre of 1:1024 or greater to L pneumophila in either the acute or convalescent phase serum; an antibody titre of 1:64 or greater to M pneumoniae; or an immunoglobulin (Ig) $\mathrm{G}$ antibody titre of 1:512 or greater, or an IgM antibody titre of $1: 16$ or greater to $C$ pneumoniae.

CAP is not a homogeneous entity, and it is useful to consider its etiology according to the following:

site of acquisition of pneumonia - community at large, nursing home;

site of care - outpatients, inpatients, intensive care unit, nursing home;

immune status - exogenous immunosuppression or human immunodeficiency virus (HIV) infection; and specific comorbid illness such as COPD. 
TABLE 3

Etiology of nursing home-acquired pneumonia

\begin{tabular}{|c|c|c|c|c|c|c|c|c|c|c|}
\hline \multirow[b]{2}{*}{ Reference } & \multirow[b]{2}{*}{$\mathrm{N}$} & \multicolumn{9}{|c|}{ Etiology (\%) } \\
\hline & & $\begin{array}{c}S \\
\text { pneum }\end{array}$ & $\begin{array}{c}C \\
\text { pneum }\end{array}$ & $\underset{\text { influen }}{H}$ & $\begin{array}{c}S \\
\text { aureus }\end{array}$ & $\begin{array}{c}M \\
\text { catarr }\end{array}$ & $\begin{array}{c}K \\
\text { pneum }\end{array}$ & $\begin{array}{l}\text { Other } \\
\text { AGNRs }\end{array}$ & Aspiration & Unknown \\
\hline 24 & 35 & $9(26)$ & & $2(6)$ & $9(26)$ & & $14(40)$ & & & 0 \\
\hline 10 & 131 & $9(6.8)$ & & $1(0.8)$ & $7(5.3)$ & & & $7(5.3)$ & $19(14.5)$ & 77 (59) \\
\hline 25 & 104 & $31(29.8)$ & & $20(19)$ & $11(10.5)$ & $4(3.8)$ & & $24(23)$ & & $14(13)$ \\
\hline 26 & 56 & $5(8.9)$ & & $4(7.1)$ & $1(1.8)$ & $3(5.5)$ & & & & $43(77)$ \\
\hline 27 & 115 & $7(6)$ & & $3(2.5)$ & $2(1.7)$ & & 7 (16) & $20(17)$ & & $83(72.8)$ \\
\hline $28^{*}$ & 30 & & $2(6.6)$ & & & & & & & $23(76.7)$ \\
\hline Total & 471 & 61 (12.9) & & $30(6.4)$ & $30(6.4)$ & $7(1.5)$ & $21(4.4)$ & $51(10.8)$ & & $240(51)$ \\
\hline $95 \% \mathrm{Cl}$ & & 1.2 to 29.7 & & -1.9 to 15 & & -3.5 to 21 & & & & 13.6 to 85 \\
\hline
\end{tabular}

TABLE 4

Etiology of community-acquired pneumonia requiring admission to an intensive care unit (ICU)

\begin{tabular}{|c|c|c|c|c|c|c|c|c|c|c|}
\hline \multirow[b]{2}{*}{ Reference } & \multirow[b]{2}{*}{ Location } & \multirow[b]{2}{*}{ Date } & \multirow[b]{2}{*}{$\mathrm{N}$} & \multirow[b]{2}{*}{$S$ pneum } & \multicolumn{3}{|c|}{ Etiology (\%) } & \multirow[b]{2}{*}{ Unknown } & \multirow[b]{2}{*}{ Ventilated } & \multirow[b]{2}{*}{ Mortality } \\
\hline & & & & & L pneum & AGNRs & $S$ aureus & & & \\
\hline 30 & Spain & $\begin{array}{c}1988 \text { to } \\
1990\end{array}$ & 58 & $13(37)$ & $8(22.8)$ & $4(11.4)$ & & $39.6 \%$ & $72 \%$ & $22.4 \%$ \\
\hline 31 & $\begin{array}{l}\text { United Kingdom } \\
\text { ( } 25 \text { hospitals) }\end{array}$ & 1987 & 60 & $11(18)$ & $7(12)$ & & $2(3)$ & $30 \%$ & $88 \%$ & $48 \%$ \\
\hline $32^{*}$ & France & $\begin{array}{c}1987 \text { to } \\
1989\end{array}$ & 132 & $43(32)$ & $4(3)$ & $14(11)$ & $5(4)$ & $28 \%$ & $37 \%$ & $24 \%$ \\
\hline 33 & Spain (26 ICUs) & $\begin{array}{c}1991 \text { to } \\
1992\end{array}$ & 262 & $30(11)$ & $21(8)$ & $8(3)$ & $10(4)$ & $41.2 \%$ & NS & NS \\
\hline 34 & Sweden & $\begin{array}{c}1977 \text { to } \\
1981\end{array}$ & 53 & $15(28)$ & & & $2(4)$ & $25 \%$ & $58 \%$ & $25 \%$ \\
\hline 35 & Seville, Spain & $\begin{array}{c}1985 \text { to } \\
1987\end{array}$ & 67 & $12(37.5)$ & $7(21.8)$ & $8(25)$ & & $52.3 \%$ & & $20.8 \%$ \\
\hline $36^{*}$ & Barcelona, Spain & $\begin{array}{c}1984 \text { to } \\
1987\end{array}$ & 92 & $13(14)$ & $13(14)$ & $5^{+}(5)$ & & $30 \%$ & $61 \%$ & $20 \%$ \\
\hline 37 & Lille, France & $\begin{array}{c}1987 \text { to } \\
1991\end{array}$ & 299 & $80(26.7)$ & & $52(17.3)$ & $\begin{array}{c}57(\text { Staph } \\
\text { species) (18) }\end{array}$ & $34.1 \%$ & $50 \%$ & $28.5 \%$ \\
\hline Total & & & 1023 & $217(21)$ & $60(5.8)$ & $91(8.8)$ & $76(7.4)$ & $35 \%$ & & \\
\hline $95 \% \mathrm{Cl}$ & & & & 17 to 34 & 2.6 to 17.7 & 3.3 to 17.8 & -0.28 to 13.7 & 27.5 to 42.9 & & \\
\hline
\end{tabular}

*Immunosuppressed patients excluded; ${ }^{\dagger}$ Five patients with Pseudomonas aeruginosa had bronchiectasis. AGNRs Aerobic Gram-negative rods; L pneum Legionella pneumophila; NS Not stated; S aureus Staphylococcus aureus; S pneum Streptococcus pneumoniae; Staph Staphylococcus

Pneumonia treated on an ambulatory basis: $M$ pneumoniae accounts for $17 \%$ to $37 \%$ of patients with pneumonia treated on an ambulatory basis. Table 1 gives a summary of the studies that have examined the etiology of pneumonia in outpatients $(12-15)$. It is likely that $S$ pneumoniae is underdiagnosed in this setting.

CAP requiring admission to hospital: Table 2 gives detailed information on 10 studies of CAP requiring hospitalization $(10,11,16-23)$. S pneumoniae is the most commonly implicated agent and accounts for about one-half of all cases of CAP requiring admission to hospital. The second most commonly implicated agent is $C$ pneumoniae and the third is $H$ influenzae. $L$ pneumophila accounts for $2 \%$ to $6 \%$ of cases of CAP requiring hospitalization. Aerobic Gram-negative bacilli, such as Escherichia coli and Klebsiella species, are uncommon causes of CAP but are important considerations in patients who require admis- sion to an intensive care unit (ICU). Mycobacterium tuberculosis must always be considered as a potential cause of CAP.

Nursing home-acquired pneumonia: Data from six studies of nursing home-acquired pneumonia are presented in Table 3 . $S$ pneumoniae is the most commonly isolated organism; however, aerobic Gram-negative bacilli such as Klebsiella species are commonly isolated from sputum of these patients. The problem is distinguishing colonization from infection.

Pneumonia in patients with chronic obstructive pulmonary disease: $S$ pneumoniae, $H$ influenzae, Legionella species and viridans streptococci were most commonly implicated in one study (29).

Severe CAP: A number of pathogens may be responsible for severe infection requiring treatment in an ICU (Table 4). Initial treatment must, at the least, cover $S$ pneumoniae, Legionella species, $H$ influenzae and aerobic Gram-negative bacilli. 
Polymicrobial infection: The issue of microbial etiology of CAP is further complicated by the fact that doctors now realize that more than one pathogen may be responsible for disease in any given patient. Such mixed infections are well known in hospital-acquired pneumonia, and in one study (38), it was shown that multiple pathogens were present in over onehalf of the patients studied. In CAP, the incidence of mixed infections appears to be lower, ranging from $2.7 \%$ to $10 \%$ in the studies of patients requiring admission to hospital $(16,39,40)$.

\section{DIAGNOSIS}

The subject of diagnostic testing of patients with CAP has generated considerable debate among pulmonologists and infectious disease specialists. The recommendations have ranged from the limited testing recommended by the ATS guidelines and the European Study on CAP (ESOCAP) Committee to the more extensive testing recommended by the IDSA $(2,3,41)$.

There are many advantages to determining a specific etiological agent including selecting the optimal drug to deal with the offending pathogen(s); reducing antibiotic abuse in terms of cost, resistance and adverse drug reactions; and identifying organisms that have potential epidemiological significance such as $M$ tuberculosis, Legionella species and drug-resistant $S$ pneumoniae. Unfortunately, the reality of current clinical practice is that, despite extensive diagnostic testing even in medical centres interested in the epidemiology of pneumonia, a specific etiological agent will not be found in one-third to one-half of cases $(10,16)$. With the possible exception of a sputum Gram stain, the information obtained comes at a time when the most significant decisions regarding antimicrobial therapy have already been made. Although studies assessing the direct impact of diagnostic testing on clinical outcomes have not been performed, a body of evidence is emerging to suggest that knowledge of the pathogen may not affect the clinical outcome (35). Antibiotics found to be initially effective against the target pathogen are associated with better outcomes, but the identification of that target pathogen has no beneficial effect on outcome (42). Identification of the organism after the initial incorrect choice of empirical therapy and subsequent correction of therapy to cover the offending pathogen does not appear to affect outcome (37). Woodhead and colleagues (43) found that in routine clinical practice (as opposed to carefully conducted prospective diagnostic investigations), causative pathogens are found in approximately $25 \%$ of cases, but the results of these investigations change therapy in less than $10 \%$ of cases. They concluded that routine microbial investigation of all adults admitted to hospital was not helpful and was probably unnecessary.

The authors of the current Canadian document have made recommendations for investigations based upon the severity of illness of the patient. This is reflected in the site of care selected by the physician and, accordingly, these recommendations will be site specific. Recommendations for patients deemed well enough to be treated on an ambulatory basis are different from those for patients ill enough to require hospitalization, either in a general ward or an ICU.

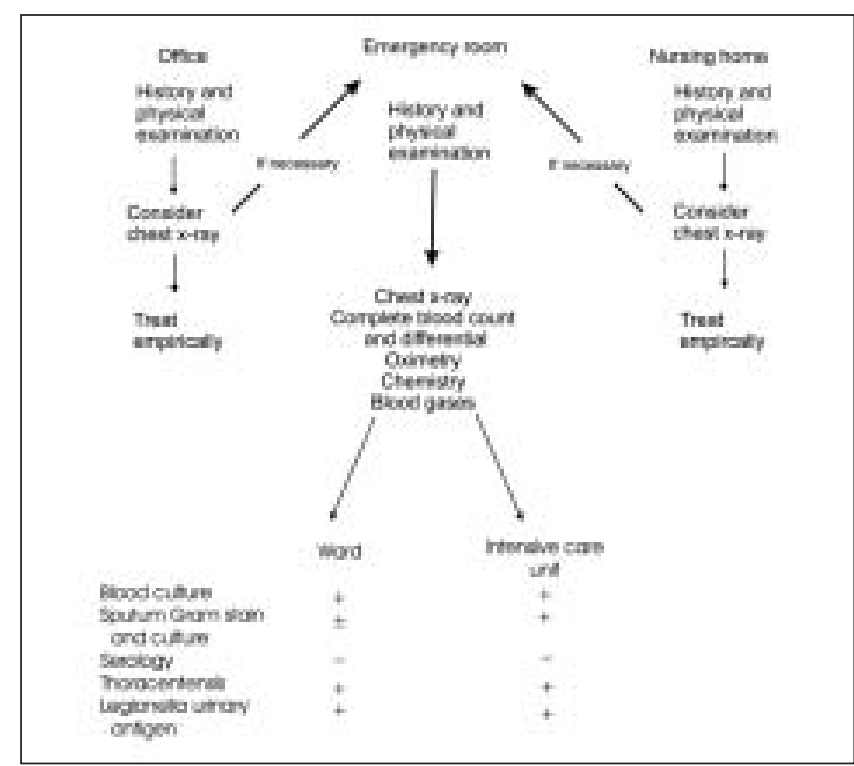

Figure 1) Diagnostic algorithm for community-acquired pneumonia. + Recommended; - Not recommended; \pm Recommended under certain specific circumstances

Clinical evaluation: Patients presenting with a new onset of a cough, purulent tracheobronchial secretions, fever and focal respiratory abnormalities on physical examination should be suspected of having pneumonia (Figure 1). It is not possible to predict accurately the offending pathogen based on the initial clinical presentation, even when multiple clinical variables are used $(16,44)$. The ability of physicians to obtain this information reliably is unknown, and the relevance of this information has not been determined (45). Interobserver variability, particularly in the determination of abnormal physical findings, is significant, and the sensitivity and specificity of history and physical examination are unknown (46). However, the clinical assessment (history and physical examination) is the foundation on which further assessment is judged and, therefore, is mandatory for all patients despite these limitations (level III evidence).

Chest radiograph: Under most circumstances, a chest radiograph is recommended as part of the routine evaluation of a patient suspected of having pneumonia (level II evidence). The advantages of a chest radiograph are that the diagnosis of pneumonia is strengthened (but not confirmed) by the presence of an infiltrate, information regarding etiology and prognosis may be obtained in occasional cases, and alternative diagnoses may be suggested. However, the panel realizes that in some instances a chest radiograph may not be performed, for example, in a nursing home patient or where poor access to radiographical equipment would require a major effort to move the patient. Under these circumstances, the panel recognizes that a trial of empirical therapy without radiographical confirmation of the diagnosis is a reasonable, although not ideal, approach (level III evidence).

Although the chest radiograph is the standard method of confirming the diagnosis of pneumonia, it is less sensitive than high resolution computed tomography (CT) scans for detecting pulmonary infiltrates, but the significance of this ob- 
servation remains to be determined (47) (level II evidence). Interobserver agreement among radiologists in the interpretation of chest radiographs ranges from $56 \%$ to $85.4 \%$; chest physicians and radiologists perform similarly. Although several prediction rules have been developed to assist the physician to reduce the number of chest radiographs ordered, these rules appear to be no better than clinical judgment (48) (level II evidence).

Laboratory assessment: Unless clinical or radiographical findings suggest risk factors for a poor outcome, the routine laboratory assessment of ambulatory patients suspected of having CAP is unnecessary (level III evidence). Once a patient has been directed to the emergency department for further assessment based on the initial clinical and radiographical findings, a complete blood count, electrolytes, liver function studies, renal function studies and an assessment of oxygen saturation are recommended (level II evidence) (Figure 1). Significant abnormalities of these laboratory tests have been identified as risk factors for a complicated hospital course or mortality. They have been used in the prediction rule developed by Fine and co-workers (49), and they have been validated prospectively for mortality risk. The panel recommends that these tests be performed routinely in all patients referred to the emergency department to help assess the severity of illness (level II evidence). Although this score can be used to evaluate mortality risk, it has not been validated as a predictor of hospital admission. There is no evidence to suggest that these investigations are useful in the routine assessment of patients in any other clinical setting (physician's office or nursing home). The panel recommends that arterial blood gases be considered for patients with COPD because oxygen saturation assessment will not inform the physician of hypercapnic respiratory failure (level III evidence). If patients do not have specific risk factors for a complicated course or mortality, and there are no other reasons for admission, the physician will in all likelihood select empirical therapy and discharge the patient from the emergency department.

\section{Microbiological assessment}

Sputum Gram stain and culture: For the majority of patients treated on an outpatient basis, no specific microbiological investigations are recommended (level II evidence). Direct staining of sputum may be diagnostic for infections caused by Mycobacterium species, Legionella species, Pneumocystis carinii and endemic fungi. Clinical circumstances should dictate the use of these tests for individual patients (risk of exposure, residence in an endemic area, compatible clinical picture). Suspicion of possible pneumococcal infection based on the results of the Gram stain as a rapid diagnostic tool may be particularly helpful in regions where significant pneumococcal resistance is problematic, and where the initial empirical therapeutic choices may change. For patients admitted to the hospital ward, the panel recommends that sputum Gram stain and culture be obtained if an adequate sample (less than 25 squamous epithelial cells/low power field on cytological screening, rapid assessment within 1 to $2 \mathrm{~h}$ of production of the sample, properly trained staff to interpret the results) can be obtained before administration of an antibiotic (level II evidence). Ther- apy should not be delayed in acutely ill patients if there is difficulty obtaining an adequate specimen. Given these constraints, it seems likely that many admitted patients will be started on empirical therapy without the benefit of a sputum Gram stain or culture. For patients admitted to the ICU, a more concerted effort to obtain lower respiratory tract secretions is recommended (level III evidence). Because these patients are monitored closely and may be intubated, it is more likely that an interpretable sample will be obtained.

A review of the extensive literature on sputum Gram stain has indicated that the test is neither sensitive nor specific for the diagnosis of etiological agent in patients with CAP (50). There is considerable inter- and intraobserver variability in the interpretation of the Gram stain results (51). Most of the studies examining the role of this test have depended upon sputum culture as the reference standard. Sputum culture is notorious for its poor test characteristics and, thus, using it to judge the quality of a Gram stain is problematic at best and misleading at worst. The routine use of sputum Gram stain, therefore, cannot be recommended (level II evidence). Routine sputum culture is neither sensitive nor specific. Among patients with pneumococcal pneumonia verified using reliable sources (blood culture, transtracheal aspirate, bronchoalveolar lavage), simultaneous sputum cultures are positive in only $50 \%$ of patients (52). Particularly in patients with COPD but in other patients as well, false-positive cultures related to chronic colonization render the interpretation of sputum cultures problematic at best in most situations.

Blood cultures: The panel recommends that two blood cultures be obtained from all hospitalized patients (level II evidence). Bacteremia is present in $6.6 \%$ to $17.6 \%$ of all hospitalized patients with CAP. Although patients with HIV are predisposed to pneumococcal pneumonia, pneumococcal bacteremia is not more common in HIV-infected individuals than in noninfected patients (39). The incidence of bacteremia in ambulatory patients with CAP is lower, but the precise figure is unknown (53). Among patients admitted to the ICU with CAP, the incidence of bacteremia is higher, ranging from $10.3 \%$ to $27 \%$. The administration of antibiotics before hospital admission reduces the diagnostic yield of blood cultures. Among patients with bacteremia, the most common pathogen is $S$ pneumoniae, and pneumococcal pneumonia is complicated by bacteremia more frequently than pneumonia caused by other organisms. Although bacteremic patients have a higher mortality than do nonbacteremic patients, this may reflect host factors and severity of illness rather than the bacteremia itself. The exception to this may be among patients with recurrent bacteremia or those who are HIV-positive.

Thoracentesis: The panel recommends diagnostic thoracentesis in any patient suspected of CAP with a significant pleural fluid collection (greater than $10 \mathrm{~mm}$ in thickness on the lateral decubitus radiographical view) (54) (level II evidence). The incidence of pleural effusion associated with pneumonia ranges from $36 \%$ to $57 \%$, and is most common in patients with pneumococcal pneumonia (55). Patients presenting later in the course of their pneumonia and those who are bacteremic are more likely to have a parapneumonic effusion (56). Anaerobes 
are the most common cause of frank empyema, occurring either alone or in conjunction with aerobes (57). Patients with pneumococcal pneumonia and parapneumonic effusions, even with positive pleural fluid bacteriology, show a relatively good response to antimicrobial therapy and may not require drainage (54).

Serology: The panel recommends that serology not be performed as part of the routine management of patients with CAP (level II evidence). These tests are usually not helpful in the early management of CAP patients because the results of acute and convalescent titres are required before ascribing clinical illness to these pathogens. Cold agglutinins are neither sensitive nor specific to detect infection with $M$ pneumoniae and are not recommended (58) (level II evidence). Serological response to Mycoplasma, Chlamydia and Legionella species usually takes weeks to develop after symptoms occur, reducing the value of these investigations except for epidemiological purposes.

Legionella urinary antigen: The panel recommends the Legionella species urinary antigen test as part of the routine management of patients with severe CAP, especially those admitted to the ICU (level II evidence). This test identifies only $L$ pneumophila serogroup 1 , which is the most common serogroup causing clinical illness. The test has a sensitivity of $70 \%$ and a specificity of $100 \%$, and is easily and rapidly performed (59). A negative urinary antigen test does not exclude the diagnosis, particularly if it is caused by organisms other than $L$ pneumophila serogroup 1 , but a positive test is diagnostic of infection.

DNA probes and amplification: DNA probes and amplification tools are being rapidly developed to assist clinicians with the rapid and accurate diagnosis of problem pathogens such as $C$ pneumoniae or M pneumoniae. These organisms can be rapidly identified from a single throat swab (60). However, the role of these new tests is under investigation, and recommendations cannot be made until their test properties have been clarified.

Invasive procedures: The panel does not recommend the routine use of invasive testing in patients suspected of having CAP (level II evidence). There may, however, be circumstances when bronchoscopy, bronchoalveolar lavage, protected specimen brush or percutaneous lung needle aspiration may be useful, such as in patients with fulminant pneumonia or those unresponsive to a standard course of antimicrobial therapy (61).

Summary: The panel recommends few investigations as part of the routine management of patients with CAP, especially those treated on an ambulatory basis. As the severity of illness increases and the risk factors for a complicated course or mortality increase, the panel recommends more intense investigations. Microbiological investigations are warranted for patients requiring admission to hospital if rapid access to competent microbiological services is available, particularly if there is a clinical suspicion of infection with unusual organisms such as $M$ tuberculosis or endemic fungi. Further studies are required to recommend more precisely the role of new technologies devised to assist in the diagnosis of specific etiological agents.

\section{TREATMENT}

The previous Canadian and ATS CAP guidelines focused on treatment recommendations based on the presence or absence of comorbid conditions, severity of illness upon clinical presentation, and whether treatment was to be given on an outpatient or inpatient basis $(1,2)$. These guidelines were well received because they provided the practicing physician with a rational and manageable approach to the initial selection of antimicrobials for the empirical treatment of this common condition. However, a number of important developments that significantly affect our decisions regarding the management of CAP have transpired since the publication of these earlier guidelines. First, the landmark studies of Fine et al $(49,62,63)$ have provided a sound basis for mortality risk prediction and decisions concerning hospital admission or discharge. This, in turn, has allowed improved judgment in choosing the initial site of care for patients and the development of critical pathways for the management of CAP in the institutional setting (64-66). Second, the increasing prevalence of antimicrobial resistance in common lower respiratory tract pathogens has meant that antimicrobial agents previously considered as first-line must be re-evaluated. Third, the availability of new macrolides and 'respiratory' fluoroquinolones with improved in vitro activity and pharmacokinetic/pharmacodynamic properties has necessitated a reassessment of both the choice and mode of administration of antimicrobial agents during initial management. On the other hand, the potential for the rapid development of resistance to these agents, $S$ pneumoniae in particular, and the recognition of serious toxicity associated with some of the newer fluoroquinolones have raised major concerns regarding the indiscriminate use of these agents. Finally, the ability to administer many agents once daily either orally, intravenously or sequentially from an intravenous to oral route, as well as the ready access to home intravenous antibiotic programs and home nursing visits, has greatly reduced the need for and duration of hospitalization of many patients with CAP.

The following update for the initial management of CAP is recommended by the consensus group. These treatment guidelines are stratified according to the site of care of the patient, ie, outpatient, nursing home resident, hospitalized patient on a general medical ward or hospitalized patient in an ICU. To make the current guidelines useful to practicing physicians, a major effort has been made to simplify the recommendations as much as possible to emphasize the general principles applicable to the majority of patients with CAP. Accordingly, recommendations for the initial empirical management of CAP are predicated on the most likely pathogens in a given population, the general trend of antibiotic resistance among respiratory pathogens locally and across Canada, and the clinical experience of these antibiotic regimens based on randomized, controlled trials. Rather than attempting to address all the possible factors that may be of dubious significance or difficult to document in a given patient, only the most important modifying factors are considered. These factors either affect oropharyngeal colonization by more resistant Gram-negative pathogens or may result in antimicrobial pressure imposed by previous antibiotic therapy. In addition, unique features of the healthcare delivery system within Canada such as the infrastructure support of its healthcare institutions including nurs- 


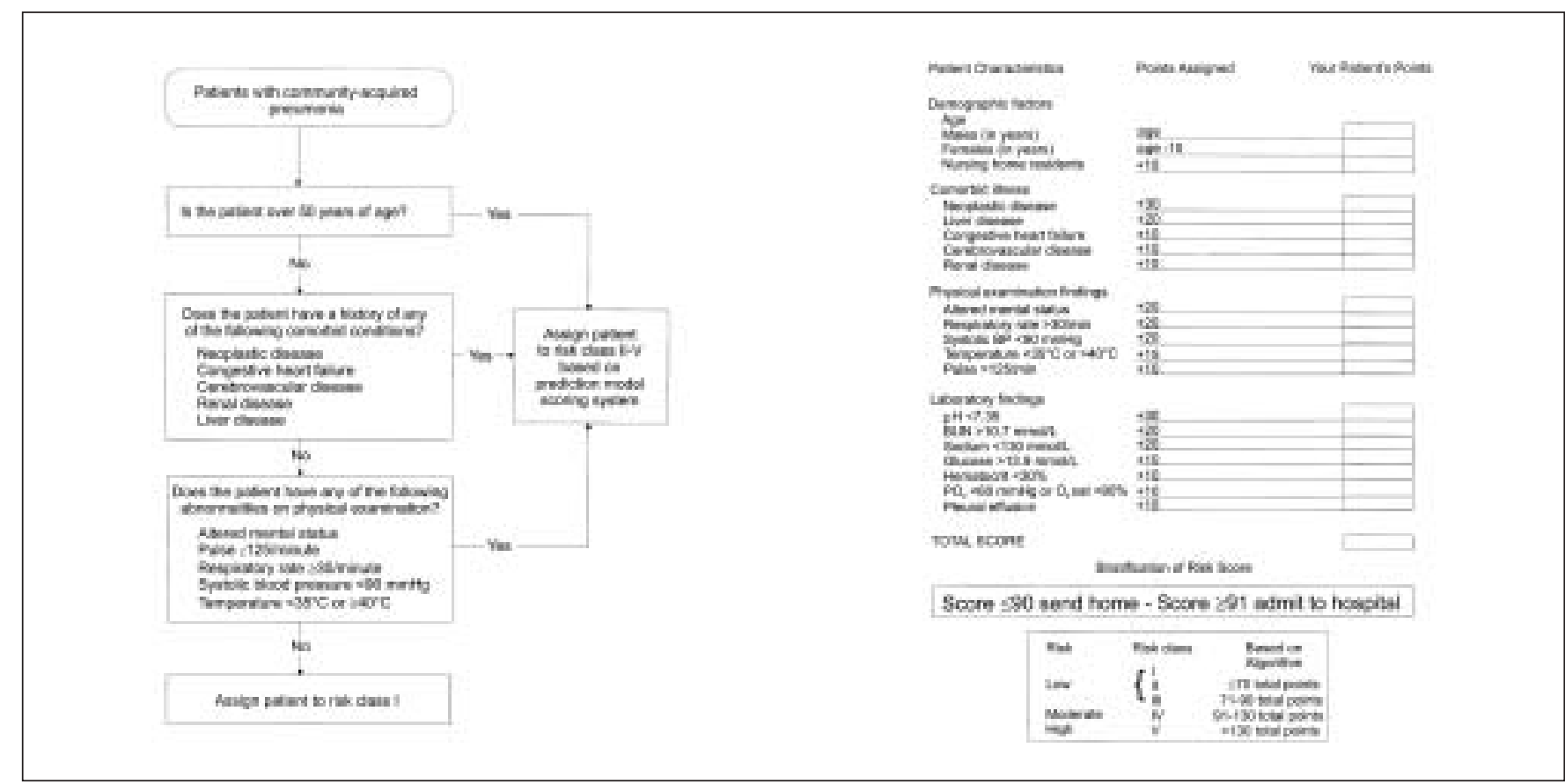

Figure 2) Prediction model for identification of patient risk for persons with community-acquired pneumonia (left). Pneumonia-specific severity of illness scoring system (right). Reproduced with permission from reference 49. BP Blood pressure; BUN Blood urea nitrogen; $\mathrm{O}_{2} \mathrm{Oxygen}^{-\mathrm{PO}_{2}} \mathrm{Partial}$ pressure of oxygen

ing homes, the availability and cost of intravenous and oral antibiotics in general, and the relative inaccessibility to parenteral antibiotics in the nursing home setting were taken into consideration.

Site-specific initial antimicrobial treatment of CAP: The authors have continued with the general approach adopted by the previous Canadian guidelines of categorizing patients into groups of those who can be treated as outpatients, those who are nursing home residents and those who require hospitalization. A detailed discussion of the studies supporting the use of the various regimens suggested here can be found in the extended version of these guidelines (4).

Patients with a pneumonia-specific severity score of greater than 90 according to the criteria of Fine et al (49) should be hospitalized (level I evidence) (Figure 2). Patients with CAP who do not require hospitalization are categorized separately into outpatients and nursing home residents. For outpatients who do not have modifying factors such as COPD or macroaspiration, treatment with a macrolide (erythromycin, azithromycin or clarithromycin) or doxycycline should suffice to treat pneumococci and 'atypical' pathogens such as $M$ pneumoniae and C pneumoniae (level II evidence) (Table 5). Both macrolides and doxycycline remain effective as monotherapy for patients with mild to moderately severe CAP based on their pneumonia-specific severity of illness score (Figure 2). Patients with COPD who have not received antibiotics or oral steroids during the previous three months can be treated in an identical fashion as patients without modifying factors with the caveat that only a newer macrolide (azithromycin or clarithromycin) be used to insure adequate coverage of $H$ influenzae. Patients with COPD and a history of use of antibiotics or oral steroids within the past three months may have an increased risk of $H$ influenzae and enteric Gram-negative bacilli, in addition to $S$ pneumoniae, $C$ pneumoniae and $L$ pneumophila infection, and a 'respiratory' fluoroquinolone is recommended. On the basis of the safety data related to serious liver injury, trovafloxacin should be reserved only for hospitalized patients whose infections are judged to be serious and life-threatening, and when the benefit is believed to outweigh the potential risk. Amoxicillin-clavulanate or a second-generation cephalosporin (eg, cefuroxime or cefprozil), each with or without a macrolide, is considered a second choice (level II evidence). If macroaspiration is suspected, a fourth-generation fluoroquinolone with enhanced activity against anaerobes (eg, moxifloxacin, gatifloxacin) should be considered (level II evidence). Alternatively, a third-generation fluoroquinolone (eg, levofloxacin) plus either clindamycin or metronidazole is appropriate (level III evidence). The choice of initial treatment of CAP for patients with HIV infection is beyond the scope of the current guidelines.

Nursing home residents with pneumonia can be evaluated with the same prediction rules for hospitalization as other patients with CAP (67) (level II evidence) (Table 1). For patients who can be treated in the nursing home setting and do not require hospitalization, a 'respiratory' fluoroquinolone or amoxicillin-clavulanate plus a macrolide is recommended as the first choice. A second-generation cephalosporin plus a macrolide is an alternative (68) (level II evidence).

Patients requiring hospitalization, including those transferred from a nursing home, can be divided into those who are managed on a general medical ward and those who require cardioventilatory support in an ICU. Treatment of patients on the general medical ward is directed at bacteremic pneumococcal pneumonia as well as $H$ influenzae, enteric Gram- 
TABLE 5

Empirical antimicrobial selection for adult patients with community-acquired pneumonia

\begin{tabular}{|c|c|c|c|}
\hline Type of pneumonia & Modifying factors and/or pathogens & First choice & Second choice \\
\hline $\begin{array}{l}\text { Outpatient without } \\
\text { modifying factors }\end{array}$ & & Macrolide* & Doxycycline \\
\hline \multirow[t]{3}{*}{$\begin{array}{l}\text { Outpatient with } \\
\text { modifying factors }\end{array}$} & $\begin{array}{l}\text { COPD (no recent antibiotics or oral } \\
\text { steroids within past } 3 \text { months) }\end{array}$ & Newer macrolides ${ }^{\dagger}$ & Doxycycline \\
\hline & $\begin{array}{l}\text { COPD (recent antibiotics or oral steroids } \\
\text { within past } 3 \text { months) - Haemophilus } \\
\text { influenzae and enteric Gram-negative } \\
\text { rods }\end{array}$ & 'Respiratory' fluoroquinolone $\mathrm{e}^{\ddagger}$ & $\begin{array}{l}\text { Amoxicillin-clavulanate }+ \text { macrolide } \\
\text { or second-generation } \\
\text { cephalosporin }+ \text { macrolide }\end{array}$ \\
\hline & $\begin{array}{l}\text { Suspected macroaspiration - oral } \\
\text { anaerobes }\end{array}$ & $\begin{array}{l}\text { Amoxicillin-clavulanate } \pm \text { macrolide, } \\
\text { or fourth-generation fluoroquinolone } \\
\text { (eg, moxifloxacin) }\end{array}$ & $\begin{array}{l}\text { Third-generation fluoroquinolones }{ }^{\ddagger} \\
\text { (eg, levofloxacin) plus clindamycin } \\
\text { or metronidazole }\end{array}$ \\
\hline $\begin{array}{l}\text { Nursing home residents } \\
\text { in nursing home }\end{array}$ & $\begin{array}{l}\text { Streptococcus pneumoniae, enteric Gram- } \\
\text { negative rods, } H \text { influenzae }\end{array}$ & $\begin{array}{l}\text { 'Respiratory' fluoroquinolone }{ }^{\ddagger} \text { alone } \\
\text { or amoxicillin-clavulanate }+ \\
\text { macrolide }\end{array}$ & $\begin{array}{l}\text { Second-generation cephalosporin }+ \\
\text { macrolide }\end{array}$ \\
\hline $\begin{array}{l}\text { Nursing home residents } \\
\text { in hospital }\end{array}$ & & $\begin{array}{l}\text { Identical to treatment for other } \\
\text { hospitalized patients (see below) }\end{array}$ & \\
\hline $\begin{array}{l}\text { Hospitalized patient on } \\
\text { medical ward }\end{array}$ & $\begin{array}{l}\text { S pneumoniae, } \\
\text { Legionella pneumophila, } \\
\text { Chlamydia pneumoniae }\end{array}$ & 'Respiratory' fluoroquinolone ${ }^{\ddagger}$ & $\begin{array}{l}\text { Second-, third- or fourth-generation } \\
\text { cephalosporin + macrolide }\end{array}$ \\
\hline \multirow[t]{2}{*}{$\begin{array}{l}\text { Hospitalized in intensive } \\
\text { care unit }\end{array}$} & $\begin{array}{l}\text { Pseudomonas aeruginosa not suspected } \\
\text { (S pneumoniae, L pneumophila, } \\
\text { C pneumoniae, enteric Gram-negative } \\
\text { rods) }\end{array}$ & $\begin{array}{l}\text { IV 'respiratory' fluoroquinolone + } \\
\text { cefotaxime, ceftriaxone or beta- } \\
\text { lactam/beta-lactamase inhibitor }\end{array}$ & $\begin{array}{l}\text { IV macrolide + cefotaxime, } \\
\text { ceftriaxone or beta-lactam/beta- } \\
\text { lactamase inhibitor }\end{array}$ \\
\hline & $P$ aeruginosa suspected & $\begin{array}{l}\text { Antipseudomonal fluoroquinolone } \\
\text { (eg, ciprofloxacin) plus } \\
\text { antipseudomonal beta-lactam } \\
\text { (eg, ceftazidime, carbapenem, } \\
\text { piperacillin-tazobactam, } \\
\text { carbapenem) or aminoglycoside (eg, } \\
\text { gentamicin, tobramycin, amikacin) }\end{array}$ & $\begin{array}{l}\text { Triple therapy with } \\
\text { antipseudomonal beta-lactam plus } \\
\text { aminoglycoside plus macrolide }\end{array}$ \\
\hline
\end{tabular}

${ }^{*}$ Macrolide - Erythromycin, azithromycin, clarithromycin; ${ }^{+}$Newer macrolide - Azithromycin, clarithromycin; ${ }^{*}$ Respiratory fluoroquinolone - Levofloxacin (third generation), gatifloxacin and moxifloxacin (fourth generation); trovafloxacin (fourth generation) is restricted because of potential severe hepatotoxicity. COPD Chronic obstructive pulmonary disease; IV Intravenous

negative bacilli and severe Legionella or Chlamydia species infection. Monotherapy with a 'respiratory' fluoroquinolone is the first choice (level II evidence). A second-, third- or fourthgeneration cephalosporin (eg, cefuroxime, cefotaxime, ceftriaxone, ceftizoxime or cefepime) plus a macrolide is an alternative treatment. Monotherapy with a fluoroquinolone for hospitalized ward patients offers logistical and financial advantages over combination therapy with a macrolide and a beta-lactam. There are also some data suggesting that use of a fluoroquinolone alone may be associated with a reduction in mortality $(69,70)$.

Choice of treatment for patients in the ICU depends upon whether $P$ aeruginos $a$ is a concern (eg, in patients with severe structural lung disease and patients who have recently completed a course of antibiotics or steroids). If $P$ aeruginosa is not an issue, broad spectrum aggressive coverage is still required in the form of an intravenous macrolide or 'respiratory' fluoroquinolone plus a nonpseudomonal third-generation cephalosporin (eg, cefotaxime, ceftriaxone) or a betalactam/beta-lactamase inhibitor. If $P$ aeruginosa is suspected, an antipseudomonal fluoroquinolone (eg, ciprofloxacin) plus an antipseudomonal beta-lactam (eg, ceftazidime, piperacillintazobactam or carbapenem) or an aminoglycoside (eg, gentamicin, tobramycin or amikacin if antibiotic resistance is not a major concern) should be used (level III evidence). An alterna- tive regimen is triple therapy with an antipseudomonal betalactam plus an aminoglycoside plus a macrolide. It should be noted that whereas synergy between an antipseudomonal beta-lactam and an aminoglycoside can frequently be demonstrated for $P$ aeruginosa in vitro, such synergistic interaction is uncommon between a fluoroquinolone and an aminoglycoside $(71,72)$. An additive effect can be expected while antagonism is rare. There are insufficient efficacy data to recommend trovafloxacin, either alone or in combination with an antipseudomonal beta-lactam, as the initial empirical treatment of serious $P$ aeruginosa infections at the present time.

It is important to recognize that these recommendations are derived from a consensus of experts and are not entirely based on evidence from randomized, controlled trials. Once an etiological agent has been appropriately identified, its in vitro susceptibility confirmed and infection with a copathogen excluded, initial empirical therapy should be modified to a narrower focus and directed at the specific pathogen(s) whenever possible (Table 6).

Unfortunately, there has never been an appropriately designed randomized, controlled trial to determine specifically the duration of antibiotic therapy for CAP. Most physicians, including members of this committee, treat for one to two weeks depending upon the clinical response of the patient. 
TABLE 6

Specific therapy for selected pathogens in community-acquired pneumonia (CAP)

\begin{tabular}{|c|c|}
\hline Pathogen & Therapy \\
\hline \multicolumn{2}{|l|}{ Streptococcus pneumoniae } \\
\hline Penicillin sensitive (MIC $0.1 \mathrm{mg} / \mathrm{L})$ & Oral penicillin G, amoxicillin, cephalosporin or macrolide \\
\hline Intermediate resistance (MIC $1 \mathrm{mg} / \mathrm{L})$ & Amoxicillin (500 mg tid PO) or cefuroxime (500 mg bid PO) \\
\hline High level resistance (MIC $2 \mathrm{mg} / \mathrm{L})$ & $\begin{array}{l}\text { Penicillin G (2 MU every } 6 \text { h IV), cefotaxime (1 g every } 8 \text { h IV), or ceftriaxone (1 g every } 24 \text { h IV), } \\
\text { or 'respiratory' fluoroquinolone* }\end{array}$ \\
\hline $\begin{array}{l}\text { CAP with high level resistance and } \\
\text { associated meningitis }\end{array}$ & Vancomycin or 'respiratory' fluoroquinolone* \\
\hline Haemophilus influenzae & Cephalosporin (second or third generation) or beta-lactam/beta-lactamase inhibitor \\
\hline Moraxella catarrhalis & Cephalosporin (second or third generation) or beta-lactam/beta-lactamase inhibitor \\
\hline Respiratory anaerobes & $\begin{array}{l}\text { Beta-lactam/beta-lactamase inhibitor or third-generation fluoroquinolone (eg, levofloxacin) + either } \\
\text { clindamycin or metronidazole, or fourth-generation fluoroquinolone (eg, moxifloxacin) }\end{array}$ \\
\hline \multicolumn{2}{|l|}{ Staphylococcus aureus } \\
\hline Methicillin-sensitive & Oxacillin or cloxacillin \\
\hline Methicillin-resistant & Vancomycin \\
\hline Enteric Gram-negative bacilli & Cephalosporin (third or fourth generation) \pm aminoglycoside \\
\hline Pseudomonas aeruginosa & Ciprofloxacin or aminoglycoside, each + antipseudomonal beta-lactam ${ }^{+}$ \\
\hline Legionella species & Macrolide \pm rifampin or fluoroquinolone \\
\hline Chlamydia pneumoniae & Doxycycline or macrolide \\
\hline Mycoplasma pneumoniae & Doxycycline or macrolide \\
\hline Coxiella burnetii (Q fever) & Tetracycline \\
\hline
\end{tabular}

Assessment of the response to initial treatment: The rate of clinical response of patients with CAP to antimicrobial therapy depends on the pathogen as well as host factors (73). However, a subjective response is usually noted within three days of initiating treatment. Objective parameters are the resolution of respiratory symptoms (cough or dyspnea), defervescence of fever, improvement in the arterial partial pressure of oxygen and serial chest radiographs, and normalization of the leukocyte count. The length of hospital stay is often determined by the duration of intravenous antimicrobial regimens. Intravenous to oral sequential therapy is strongly recommended because it reduces the cost and shortens the length of hospital stay, and provides additional psychosocial benefit for the patient (level I evidence).

Patients who fail to respond to treatment despite what appears to be an appropriate choice of antimicrobial therapy should be re-evaluated at three to five days after the initiation of treatment. Possible reasons for failure include complicated pneumonia such as the presence of an empyema, bronchial obstruction or extrapulmonary spread of infection, superinfection or misdiagnosis of noninfectious causes (eg, congestive heart failure, neoplasm, vasculitis, sarcoidosis, drug reaction, alveolitis, pulmonary embolism or hemorrhage). Additional diagnostic procedures such as CT scan, bronchoscopy, mediastinoscopy, angiography or lung biopsy may be required.

General measures and follow-up: In addition to antimicrobial therapy, certain general principles of management should be implemented. Adequate hydration will help to clear secretions. Cough suppressants may be beneficial in patients with severe paroxysms of coughing that produce respiratory fatigue or pleuritic and chest wall pain. Oxygen therapy is indicated for hypoxemia. Significant pleural effusion (greater than $10 \mathrm{~mm}$ on lateral decubitus) or pleural empyema should be drained either by needle aspiration under CT guidance or surgically. Patients treated in the outpatient setting must be carefully monitored to ensure compliance and clinical improvement. Follow-up of the patient by telephone or a return clinic visit within 48 to $72 \mathrm{~h}$ is strongly suggested. Additional visits and a repeat chest $\mathrm{x}$-ray within two to three weeks of antimicrobial therapy may be beneficial to ensure the resolution of the pneumonia.

Prevention of CAP: The importance of pneumococcal infection in CAP is apparent, but it is also clear that during outbreaks of influenza, the influenza virus has a significant impact on CAP as well. Both of these infections may be prevented by the use of pneumococcal and influenza vaccines, respectively. The former is a polyvalent preparation containing purified capsular polysaccharide of the serotypes responsible for most of the invasive pneumococcal infections. The latter vaccine is altered on a yearly basis to contain antigens of the influenza strains that are anticipated to cause problems in the coming season.

A detailed discussion of these vaccines is beyond the scope of this document, but the interested reader is referred to the following papers for additional information (74-77). The committee supports the use of the currently available pneumococcal (level II) and influenza (level I) vaccines in unvaccinated patients at risk for infection with either of these pathogens, or in those at increased risk of complications from such infections. 
REFERENCES

1. Mandell LA, Niederman MS, and The Canadian Community Acquired Pneumonia Consensus Conference Group. Antimicrobial treatment of community acquired pneumonia in adults: A conference report. Can J Infect Dis 1993;4:25-8.

2. Niederman MS, Bass JB Jr, Campbell GD, et al, on behalf of the American Thoracic Society and the Medical Section of the American Lung Association. Guidelines for the initial management of adults with community-acquired pneumonia: diagnosis, assessment of severity, and initial antimicrobial therapy. Am Rev Respir Dis 1993;148:1418-26.

3. Bartlett JG, Breiman RF, Mandell LA, Fine TM Jr, for the Infectious Diseases Society of America. Community-acquired pneumonia in adults: Guidelines for management. Clin Infect Dis 1998;26:811-38

4. Mandell LA, Marrie TJ, Grossman RF, Chow AW, Hyland RH. Canadian Guidelines for the Initial Management of CommunityAcquired Pneumonia: An Evidence-Based Update by the Canadian Infectious Diseases Society and the Canadian Thoracic Society. Clin Infect Dis 2000;31:383-421.

5. Canadian Task Force on the Periodic Health Examination. The periodic health examination. I. Introduction. Can Med Assoc J 1986;134:721-3.

6. Dixon RE. Economic costs of respiratory tract infections in the United States. Am J Med 1985;78:45-51.

7. National Center for Health Statistics. National hospital discharge survey: Annual summary 1990. Vital Health Stat 1998; 13:1-225.

8. Koivula I, Sten M, Makela PH. Risk factors for pneumonia in the elderly. Am J Med 1994;96:313-20.

9. Lipsky BA, Boyko EJ, Inui TS, Koepsell TD. Risk factors for acquiring pneumococcal infections. Arch Intern Med 1986;146:2179-85.

10. Marrie TJ, Durant H, Yates L. Community-acquired pneumonia requiring hospitalization: 5-year prospective study. Rev Infect Dis 1989;11:586-99.

11. Marston BJ, Plouffe JF, File TM Jr, et al, on behalf of the Community-Based Pneumonia Incidence Study Group. Incidence of community-acquired pneumonia requiring hospitalization. Results of a population-based active surveillance study in Ohio. Arch Intern Med 1997;157:1709-18.

12. Berntsson E, Lagergard T, Strannegard O, Trollfors B. Etiology of community-acquired pneumonia in out-patients. Eur J Clin Microbiol 1986;5:446-7.

13. Marrie TJ, Peeling RW, Fine MJ, Singer DE, Coley CM, Kapoor WN Ambulatory patients with community-acquired pneumonia: The frequency of atypical agents and clinical course. Am J Med 1996;101:508-15.

14. Erard PH, Moser F, Wenger A, et al. Prospective study on community-acquired pneumonia diagnosed and followed up by private practitioners. CHUV, Lausanne, Switzerland. 31 st Intersceince Conference on Antimicrobial Agents and Chemotherapy. Chicago, October 1991. (Abst 56)

15. Langille DB, Yates L, Marrie TJ. Serological investigation of pneumonia as it presents to the physician's office. Can J Infect Dis 1993;4:328-32.

16. Fang GD, Fine M, Orloff J, et al. New and emerging etiologies for community-acquired pneumonia with implications for therapy. A prospective multicenter study of 359 cases. Medicine (Baltimore) 1990;69:307-16.

17. Levy M, Dromer F, Brion N, Leturdu F, Carbon C. Communityacquired pneumonia: Importance of initial noninvasive bacteriologic and radiographic investigations. Chest 1988;93:43-8.

18. Kauppinen MT, Herva E, Kujala P, Leinonen M, Saikku P, Syrjala H. The etiology of community-acquired pneumonia among hospitalized patients during a Chlamydia pneumoniae epidemic in Finland. J Infect Dis 1995;172:1330-5.

19. Burman LA, Trollfors B, Andersson B, et al. Diagnosis of pneumonia by cultures, bacterial and viral antigen detection tests, and serology with special reference to antibodies against pneumococcal antigens. J Infect Dis 1991;163:1087-93.

20. Mundy LM, Auwaerter PG, Oldach D, et al. Community-acquired pneumonia: Impact of immune status. Am J Respir Crit Care Med 1995;152:1309-15.

21. Porath A, Schlaeffer F, Lieberman D. The epidemiology of community-acquired pneumonia among hospitalized adults. J Infect 1997;34:41-8.

22. Bohte R, van Furth R, van den Broek PJ. Aetiology of communityacquired pneumonia: a prospective study among adults requiring admission to hospital. Thorax 1995;50:543-7.

23. Bates JH, Campbell GD, Barron AL, et al. Microbial etiology of acute pneumonia in hospitalized patients. Chest 1992;101:1005-12.

24. Garb JL, Brown RB, Garb JR, Tuthill RW. Differences in etiology of pneumonias in nursing home and community patients. JAMA 1978;240:2169-72

25. Phillips SL, Branaman-Phillips J. The use of intramuscular cefoperazone versus intramuscular ceftriaxone in patients with nursing home-acquired pneumonia. J Am Geriatr Soc 1993;41:1071-4

26. Drinka PJ, Gauerke C, Voeks S, et al. Pneumonia in a nursing home. J Gen Intern Med 1994;9:650-2.

27. Chow CW, Senthiragah N, Rawje M, et al. Interim report on drug utilization review of community-acquired and nosocomial pneumonia: Clinical, bacteriological and radiological spectrum. Can J Infect Dis 1994;5(Suppl C):20C.

28. Orr PH, Peeling RW, Fast M, et al. Serological study of responses to selected pathogens causing respiratory tract infection in the institutionalized elderly. Clin Infect Dis 1996;23:1240-5.

29. Torres A, Dorca J, Zalacain R, et al. Community-acquired pneumonia in chronic obstructive pulmonary disease: a Spanish multicenter study. Am J Respir Crit Care Med 1996;154:1456-61.

30. Rello J, Ouintana E, Ausina V, Net A, Prats G. A three-year study of severe community-acquired pneumonia with emphasis on outcome. Chest 1993;103:232-5.

31. The British Thoracic Society Research Committee and The Public Health Laboratory Service. The aetiology, management and outcome of severe community-acquired pneumonia on the intensive care unit. Respir Med 1992;86:7-13.

32. Moine P, Vercken JB, Chevret S, Gajdos P, on behalf of the French Study Group of Community-Acquired Pneumonia in ICU. Severe community-acquired pneumococcal pneumonia. Scand J Infect Dis $1995 ; 27: 201-6$.

33. Olaechea PM, Ouintana JM, Gallardo MS, Insausti J, Maravi E, Alvarez B. A predictive model for the treatment approach to community-acquired pneumonia in patients needing ICU admission. Intensive Care Med 1996;22:1294-300.

34. Örtqvist A, Sterner G, Nilsson JA. Severe community-acquired pneumonia: factors influencing need of intensive care treatment and prognosis. Scand J Infect Dis 1985;17:377-86.

35. Pachon J, Prados MD, Capote F, Cuello JA, Garnacho J, Verano A. Severe community-acquired pneumonia: Etiology, prognosis, and treatment. Am Rev Respir Dis 1990;142:369-73.

36. Torres A, Serra-Batlles J, Ferrer A, et al. Severe communityacquired pneumonia. Epidemiology and prognostic factors. Am Rev Respir Dis 1991;144:312-8.

37. Leroy O, Santre C, Beuscart C. A five-year study of severe community-acquired pneumonia with emphasis on prognosis in patients admitted to an intensive care unit. Intensive Care Med 1995;21:24-31

38. Bartlett JG, O'Keefe P, Tally FP, Louie TJ, Gorbach SL. Bacteriology of hospital-acquired pneumonia. Arch Intern Med 1986;146:868-71.

39. Marrie TJ. Community-acquired pneumonia. Clin Infect Dis 1994;18:501-15

40. Moine P, Vercken J-B, Chevret S, Chastang C, Gajdos P, on behalf of the French Study Group for Community-Acquired Pneumonia in the Intensive Care Unit. Severe community-acquired pneumonia: Etiology, epidemiology and prognostic factors. Chest 1994;105:1487-95.

41. European Respiratory Society. ERS Task Force Report. Guidelines for management of adult community-acquired lower respiratory tract infections. Eur Respir J 1998;11:986-91

42. Levy M, Dromer F, Brion N, Leturdu F, Carbon C. Communityacquired pneumonia: importance of initial noninvasive bacteriologic and radiologic investigations. Chest 1988;92:43-8.

43. Woodhead MA, Arrowsmith J, Chamberlain-Webber R, Wooding S, Williams I. The value of routine microbial investigation in community-acquired pneumonia. Respir Med 1991;85:313-7. 
44. Farr BM, Kaiser DL, Harrison BDW, Connolly CK. Prediction of microbial aetiology at admission to hospital for pneumonia from the presenting clinical features. Thorax 1989;44:1031-5.

45. Metlay JP, Kapoor WN, Fine MJ. Does this patient have community-acquired pneumonia? Diagnosing pneumonia by history and physical examination. JAMA 1997;278:1440-5.

46. Spiteri MA, Cook DG, Clarke SW. Reliability of eliciting physical signs in examination of the chest. Lancet 1988;1:873-5.

47. Syrjälä H, Broas M, Suramo I, Ojala A, Lahde S. High-resolution computed tomography for the diagnosis of community-acquired pneumonia. Clin Infect Dis 1998;27:358-63.

48. Emerman CL, Dawson N, Speroff T, et al. Comparison of physician judgment and decision aids for ordering chest radiographs for pneumonia in outpatients. Ann Emerg Med 1991;20:1215-9.

49. Fine MJ, Auble TE, Yearly DM, et al. A prediction rule to identify low-risk patients with community-acquired pneumonia. N Engl J Med 1997;336:243-50.

50. Reed WW, Byrd GS, Gates RH Jr, Howard RS, Weaver MJ. Sputum Gram's stain in community-acquired pneumococcal pneumonia. A meta-analysis. West J Med 1996;165:197-204.

51. Geckler RW, McAllister CK, Gremillion DH, Ellenbogen C. Clinical value of paired sputum and transtracheal aspirates in the initial management of pneumonia. Chest 1985;87:631-5.

52. Barrett-Connor E. The nonvalue of sputum culture in the diagnosis of pneumococcal pneumonia. Am Rev Respir Dis 1971;103:845-8

53. Sturmann KM, Bopp J, Molinari D, Akhtar S, Murphy J. Blood cultures in adult patients released from an urban emergency department: a 15-month experience. Acad Emerg Med 1996;3:768-75.

54. Light RW, Girard WM, Jenkinson SG, George RB. Parapneumonic effusions. Am J Med 1980;69:507-12.

55. Sahn SA. Management of complicated parapneumonic effusions. Am Rev Respir Dis 1993;148:813-7.

56. Taryle DA, Potts DE, Sahn SA. The incidence and clinica correlates of parapneumonic effusions in pneumococcal pneumonia. Chest 1978;74:170-3.

57. Varkey B, Rose HD, Kutty CPK, Politis J. Empyema thoracis during a ten-year period. Analysis of 72 cases and comparison to a previous study (1952 to 1967). Arch Intern Med 1981;141:1771-6.

58. Jacobs E. Serological diagnosis of Mycoplasma pneumoniae infections: A critical review of current procedures. Clin Infect Dis 1993;17(Suppl 1):S79-82.

59. Stout JE, Yu VL. Legionellosis. N Engl J Med 1997;337:682-7.

60. Ramirez JA, Ahkee S, Tolentino A, Miller RD, Summersgill JT. Diagnosis of Legionella pneumophila, Mycoplasma pneumoniae or Chlamydia pneumoniae lower respiratory tract infection using the polymerase chain reaction on a single throat swab specimen. Diag Microbiol Infect Dis 1996;24:7-14.

61. Örtqvist $\AA$, Kalin M, Lejdeborn L, Lundberg B. Diagnostic fiberoptic bronchoscopy and protected brush culture in patients with community-acquired pneumonia. Chest 1990;97:576-82.

62. Fine MJ, Hough LJ, Medsger AR, et al. The hospital admission decision for patients with community-acquired pneumonia. Results from the Pneumonia Patient Outcomes Research Team cohort study. Arch Intern Med 1997;157:36-44.

63. Fine MJ, Medsger AR, Stone RA, et al. The hospital discharge decision for patients with community-acquired pneumonia. Results from the Pneumonia Patient Outcomes Research Team cohort study. Arch Intern Med 1997;157:47-56.

64. Auble TE, Yealy DM, Fine MJ. Assessing prognosis and selecting an initial site of care for adults with community-acquired pneumonia. Infect Dis Clin North Am 1998;12:741-59.

65. Haddock C, Niederman MS, Stelmach WJ, Brown RB, Tice AD, Bartlett JG. Clinical pathways in an acute care setting: Community- acquired pneumonia. Infect Dis Clin Pract 1996;5(Suppl 4):S166-73.

66. Marrie TJ, Lau CY, Wheeler SL, Wong CJ, Vandervoort MK, Feagan BG, and the CAPITAL Study Investigators. A controlled trial of a critical pathway for treatment of community-acquired pneumonia. JAMA 2000;283:749-55.

67. Mylotte JM, Naughton B, Saludades C, Maszarovics Z. Validation and application of the pneumonia prognosis index to nursing home residents with pneumonia. J Am Geriatr Soc 1998;46:1538-44.

68. Muder RR. Pneumonia in residents of long-term care facilities: epidemiology, etiology, management, and prevention. Am J Med 1998;105:319-30.

69. Niederman M, Traub S, Ellison WT, et al. A double-blind, randomized, multicenter, global study in trovafloxacin with ceftriaxone plus erythromycin. 37 th Interscience Conference on Antimicrobial Agents and Chemotherapy. Toronto, September 28 to October 1, 1997. (Abst LM-72)

70. Niederman M, Church D, Haverstock D, et al. Does appropriate antibiotic treatment influence outcome in community-acquired pneumonia (CAP) and acute exacerbations of chronic bronchitis (AECB)? Abstracts of the 3rd International Moxifloxacin Symposium, Monte Carlos, February 2000. (Abst 23)

71. Chow AW, Wong J, Bartlett KH, Shafran SD, Stiver HG. Crossresistance of Pseudomonas aeruginosa to ciprofloxacin, extendedspectrum beta-lactams, and aminoglycosides and susceptibility to antibiotic combinations. Antimicrob Agents Chemother 1989;33:1368-72.

72. Visalli MA, Jacobs MR, Appelbaum PC. Determination of activities of levofloxacin, alone and combined with gentamicin, ceftazidime, cefpirome, and meropenem, against 124 strains of Pseudomonas aeruginosa by checkerboard and time-kill methodology. Antimicrob Agents Chemother 1998;42:953-5.

73. Bartlett JG. Assessment of response to antimicrobial therapy and time to discharge in patients hospitalized with communityacquired pneumonia. Infect Dis Clin Pract 1996;9(Suppl 4):S148-53.

74. Shapiro ED, Berg AT, Austrian R, et al. The protective efficacy of polyvalent pneumococcal polysaccharide vaccine. N Engl J Med 1991;325:1453-60.

75. Prevention of pneumococcal disease: recommendations of the Advisory Committee on Immunization Practices (ACIP). MMWR Morb Mortal Wkly Rep 1997;46(RR-8):1-24.

76. Butler JC, Breiman RF, Campbell JF, Lipman HB, Broome CV, Facklam RR. Pneumococcal polysaccharide vaccine efficacy. An evaluation of current recommendations. JAMA 1993;270:1826-31.

77. Prevention and control of influenza recommendations of the Advisory Committee on Immunization Practices (ACIP). Centers for Disease Control and Prevention. MMWR Morb Mortal Wkly Rep 1995;44(RR-3):1-22. 


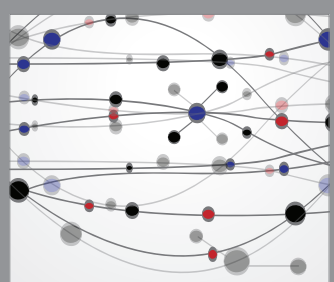

The Scientific World Journal
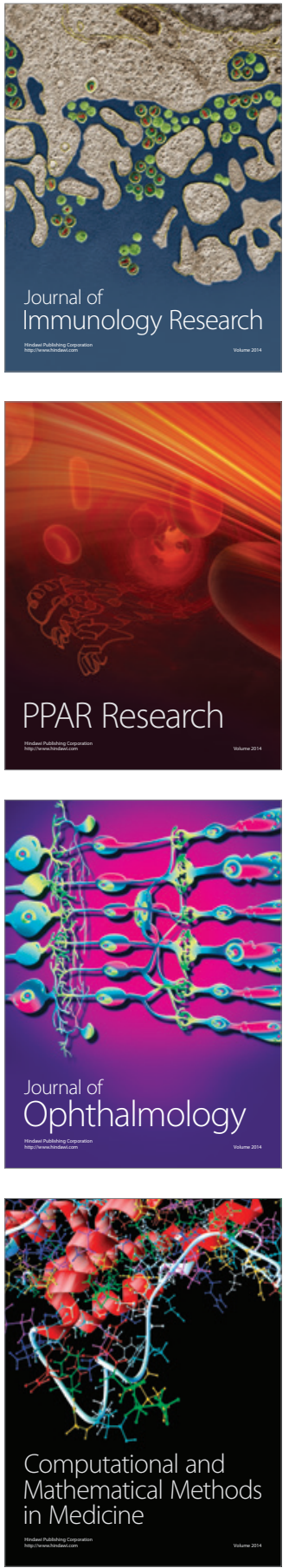

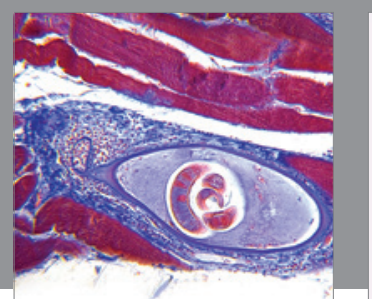

Gastroenterology Research and Practice

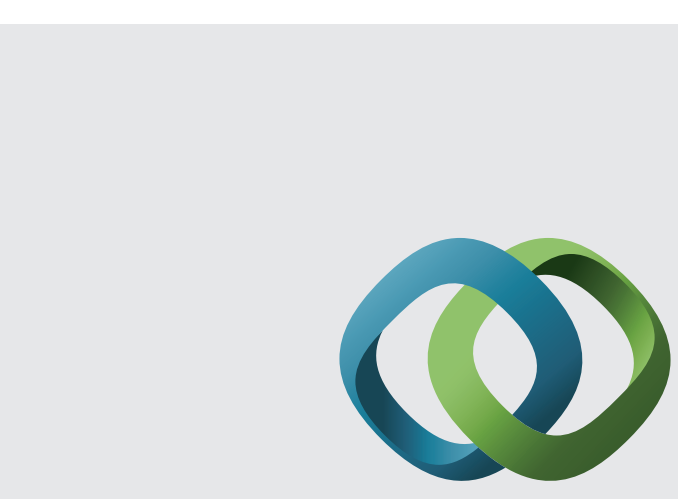

\section{Hindawi}

Submit your manuscripts at

http://www.hindawi.com
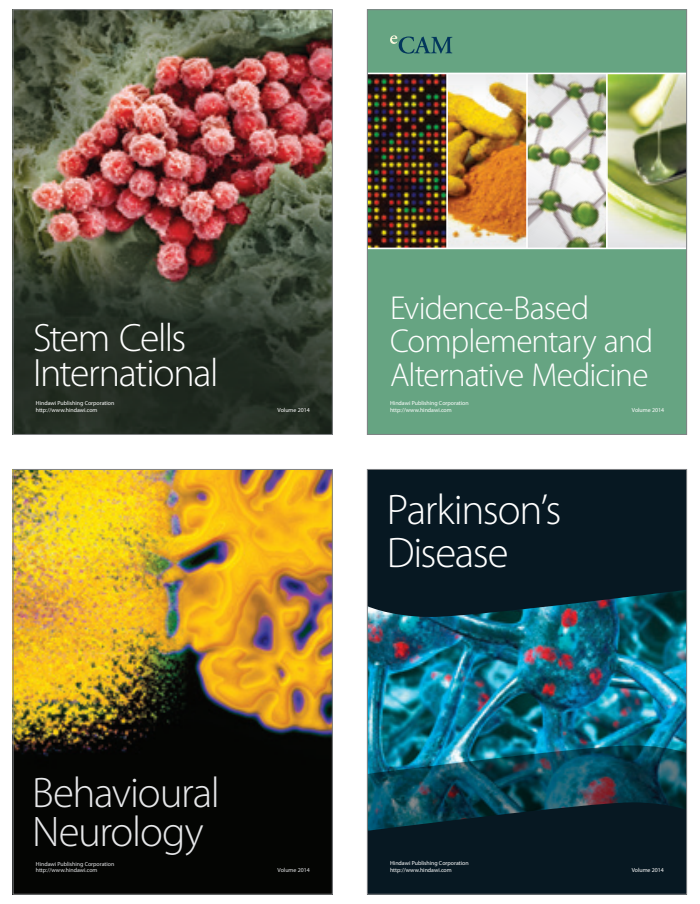
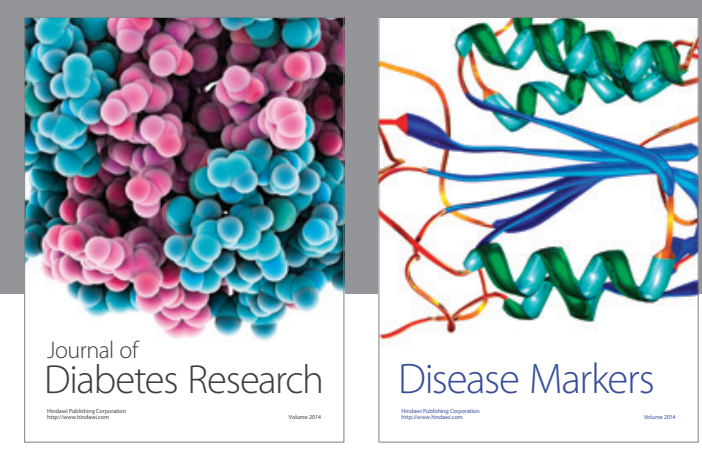

Disease Markers
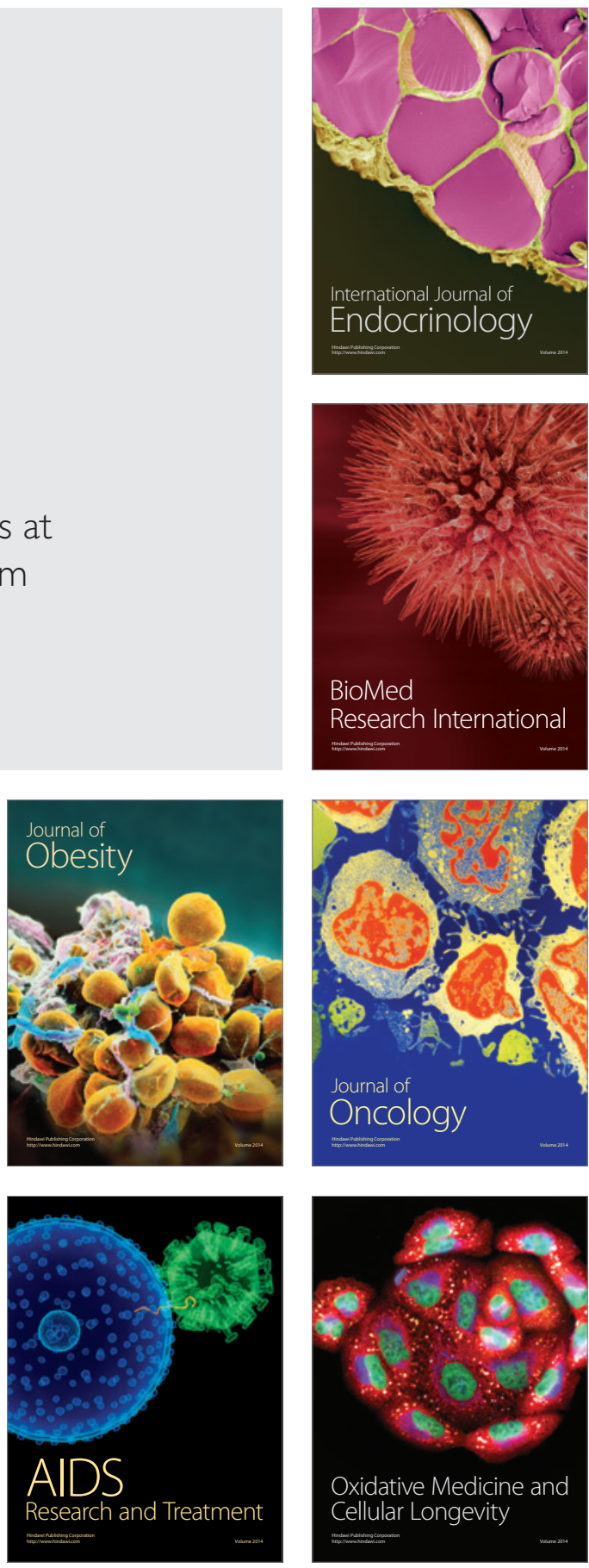